\title{
20. MINERALOGY AND CHEMICAL COMPOSITION OF CLAY MINERALS, TAG HYDROTHERMAL MOUND ${ }^{1}$
}

\author{
Anne Sturz, ${ }^{2}$ Mika Itoh, ${ }^{2}$ and Susan Smith ${ }^{3}$
}

\begin{abstract}
Herein we present preliminary results of a study of the distribution and chemical composition of clay minerals in rocks recovered from the Trans-Atlantic Geotraverse (TAG) hydrothermal mound. This study is part of Leg 158 of the Ocean Drilling Program, an effort to evaluate the subsurface secondary mineral distribution and nature of alteration at the active TAG mound, located at $26^{\circ} \mathrm{N}$ latitude on the Mid-Atlantic Ridge. X-ray diffraction analyses and petrographic and scanning electron microscopy indicate that the clay minerals include chlorite, smectite, and a mica-like clay. Chemical analyses by flame atomic absorption spectrophotometry of clay-mineral separates and inductively coupled plasma-atomic emission spectrophotometry analyses of basalt alteration rims indicate that the chlorite and smectite have similar major-element compositions and that both clay minerals have lower $\mathrm{SiO}_{2}$ and $\mathrm{Al}_{2} \mathrm{O}_{3}$ and higher $\mathrm{Fe}_{2} \mathrm{O}_{3}$ and $\mathrm{MgO}$ than bulk basalt. $\mathrm{Cu}$ and $\mathrm{Zn}$ are elevated above unaltered basalt concentrations in the smectites and chlorites and in bulk-rock alteration rims. Spatial distributions through the mound of $\mathrm{SiO}_{2} /$ $\mathrm{Fe}_{2} \mathrm{O}_{3}, \mathrm{MgO}$, and $\mathrm{Zn}$ in clay minerals and alteration rims suggest that fluids circulating through the TAG mound originate from two sources: (1) a shallowly circulating fluid that is less evolved and nearer to unaltered seawater chemical composition, and (2) a deeply circulating fluid that is more evolved fluid and changed from unaltered seawater by more extensive chemical reaction with underlying basalt. Clay-mineral compositions suggest that the southeasterly and shallow central portions of the mound are influenced by a greater proportion of the shallowly circulating, less evolved fluid, and the northwesterly and deeper central portions of the mound are influenced by a greater proportion of the deeply circulating, more evolved hydrothermal fluid.
\end{abstract}

\section{INTRODUCTION}

An important objective of Leg 158 of the Ocean Drilling Program (ODP) was to investigate the subsurface mineral distribution and mode of alteration at the Trans-Atlantic Geotraverse (TAG) hydrothermal mound, at $26^{\circ} \mathrm{N}$ latitude on the Mid-Atlantic Ridge. As part of the post-cruise research, we performed mineralogical and chemical analyses of clay-mineral separates from rocks collected between 15 and 121 meters below the seafloor (mbsf) from three areas of the TAG mound. This part of the project addressed the following objectives:

1. To determine clay mineralogical and chemical composition;

2. To investigate whether there is a correlation between secondary silicate mineralogy and selected heavy metal concentrations;

3. To follow the transfer of selected major, minor, and trace components from the unaltered basalt into secondary silicates and evolved fluids by comparing our clay-mineral data to unaltered basalt (Smith and Humphris, Chap. 17, this volume) and the black smoker fluids (Campbell et al., 1988) presently exiting from the apex of the TAG mound; and

4. To discern the distribution of and changes in chemical composition of subsurface fluids circulating through the mound using evidence assembled from clay-mineral data.

Based on observations and data acquired from remote sensing and submersible missions prior to Leg 158 (e.g. Becker et al., 1993; Rona et al., 1993; Fujioka et al., 1994; Humphris et al., 1995; Tivey et al., 1994; and references therein), the TAG hydrothermal mound is

${ }^{1}$ Herzig, P.M., Humphris, S.E., Miller, D.J., and Zierenberg, R.A. (Eds.), 1998. Proc. ODP, Sci. Results, 158: College Station, TX (Ocean Drilling Program).

${ }^{2}$ Marine and Environmental Studies Program, University of San Diego, 5998 Alcala Park, San Diego, CA 92110-2492, U.S.A. asturz@acusd.edu U.S.A

${ }^{3}$ Department of Geosciences, University of Houston, Houston, TX 77204-5503,

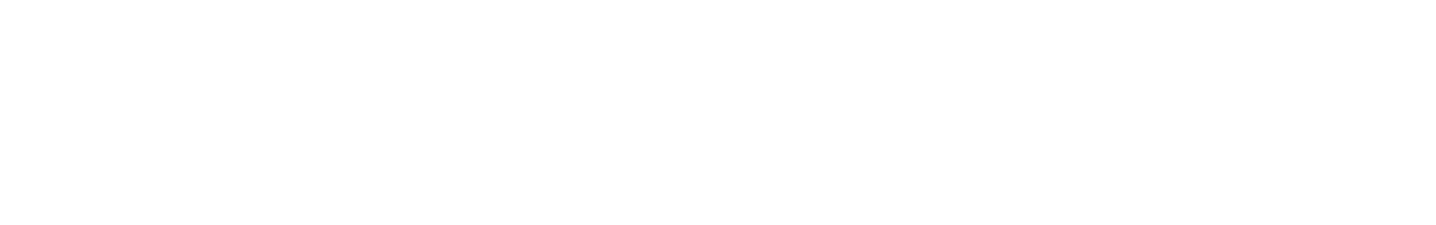

roughly circular, about $200 \mathrm{~m}$ in diameter, with its highest part about $50 \mathrm{~m}$ above the adjacent basalt plain (Fig. 1). The mound has several distinct regions of presently active low- and high-temperature fluid flow associated with metalliferous materials. The highest part of the mound (northwest center) is occupied by a cluster of chalcopyriteanhydrite-rich black smoker chimneys (Black Smoker Complex) that emit $>360^{\circ} \mathrm{C}$ fluids (Campbell et al., 1988; Von Damm, 1995). Bathymetric profiles of the mound exhibit two terraces downslope from the Black Smoker Complex that are broader and more regular to the east and south and narrower and more rugged to the north and west. The two terraces are interpreted by Tivey et al. (1994) to represent two phases of active mound growth. The upper terrace $(3644 \mathrm{~m}$ water depth) to the southeast of the Black Smoker Complex is a broad platform with an irregular surface and relatively high heat flow. The upper terrace to the west of the Black Smoker Complex is narrower, more irregular, and is a zone of coherent relatively low heat flow considered by Becker et al. (1993) to be a region of seawater entrainment into the mound. The lower terrace ( $3650 \mathrm{~m}$ water depth) is a broad, irregular platform to the southeast of the Black Smoker Complex. About $70 \mathrm{~m}$ to the southeast of Black Smoker Complex and on the lower terrace, there is a region of white smokers (the Kremlin area) venting fluids with temperatures between $260^{\circ}$ and $300^{\circ} \mathrm{C}$.

\section{Site 957}

Drilling during Leg 158 completed seventeen holes (Site 957A957Q) drilled to various depths at five locations (TAG 1-TAG 5) around the hydrothermal mound and providing northwest-southeast and north-south cross sections across the mound (Fig. 1). TAG-1 is located east of the Black Smoker Complex on the upper terrace. The combined TAG-1 holes (Holes 957C, 957D, 957E, 957F, 957G, and 957L) penetrated to $125 \mathrm{mbsf}$, the deepest penetration of the five locations. The composite depth of rocks cored at TAG-1 provide a section through the hydrothermal mound and into the stockwork zone below. TAG-2 (Holes 957A, 957B, 957H, and 957N) is located on the lower terrace east of Black Smoker Complex, in the white smoker Kremlin area, and penetrated to 54.3 mbsf. TAG-3 drilled a single 

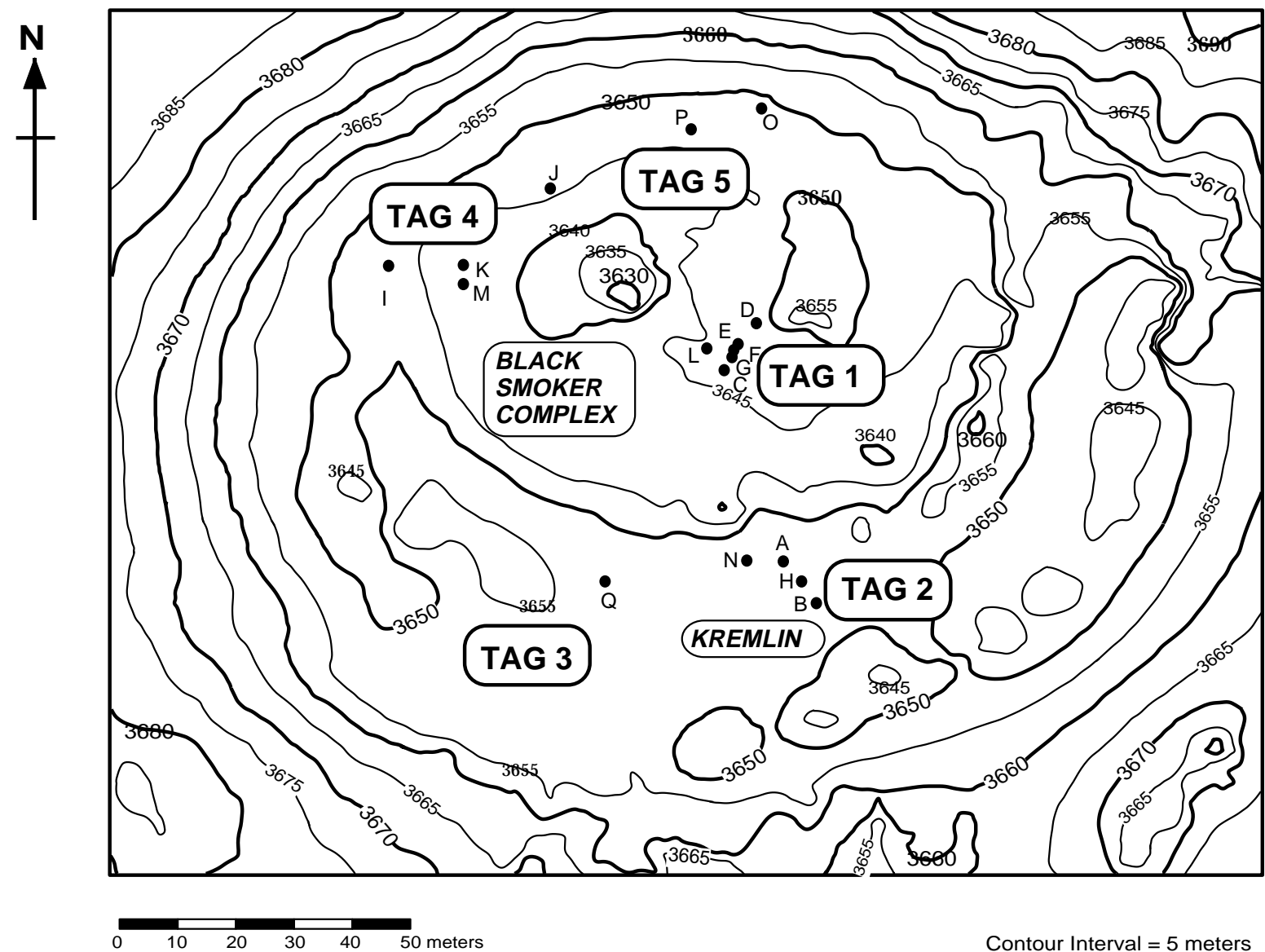

Contour Interval = 5 meters

Figure 1. Topographic map of the active TAG mound showing locations of TAG-1, TAG-2, TAG-3, TAG-4, TAG-5, and the locations of Holes 957A through 957Q.

hole (Hole 957Q) to $14.5 \mathrm{mbsf}$ on the lower terrace south of the Black Smoker Complex and west of the TAG-2 area. TAG-4 (Holes 957I, $957 \mathrm{~J}, 957 \mathrm{~K}$, and $957 \mathrm{M})$, located on the upper terrace on the western side of the mound, penetrated to $51.2 \mathrm{mbsf}$ through mound material and into basaltic basement. Two holes (Holes 957P and 957O) on the upper terrace to the north of the Black Smoker Complex, TAG-5, had a combined penetration to $59.4 \mathrm{mbsf}$. Preliminary shipboard interpretation of cored rocks recovered by drilling at the TAG mound suggest the following stratigraphic sequence (Humphris, Herzig, Miller, et al., 1996; Fig. 2):

1. The upper few meters of the mound are dominated by porous to massive pyrite and pyrite breccias (lithology 1 in Table 1) derived from sulfide crusts, chimney talus, and near-surface hydrothermal precipitates. As much as the upper $25 \mathrm{~m}$ of the mound may be accumulating through primary sulfide formation and hydrothermal reworking and recrystallization to form massive sulfide breccias.

2. Below the near-surface hydrothermal precipitates is an anhydrite-rich zone that is thicker toward the interior of the mound ( $30 \mathrm{~m}$ in the TAG-1 area) than near the periphery of the mound (0-10 $\mathrm{m}$ in the regions of TAG 2 to TAG 5). The anhydriterich zone consists of pyrite-anhydrite and pyrite-anhydrite-silica breccias. Anhydrite may contribute to mound growth by subsurface deposition related to entrainment of seawater through the shallow portions of the mound.

3. Below the anhydrite-rich zone is a zone of quartz mineralization dominated by massive pyrite breccia grading to pyrite-silica breccia (lithology 2 in Table 1), grading to chloritized basalt (lithology 3 in Table 1) and weakly mineralized basalt (lithology 4 in Table 1). The silicified breccias and chloritized basalt may represent the upper part of the stockwork zone and uppermost basement.

Local bottom water and borehole fluids were recovered using the water-sampling temperature probe (WSTP; Humphris, Herzig, Miller, et al., 1996). The borehole fluid was recovered from Hole 957C at 28.65 mbsf. Based on shipboard chemical analyses of the borehole fluid, the fluid recovered is dominated by surface seawater pumped into the hole during drilling operations. Thus, the concentrations of dissolved ions measured are artifacts of the drilling process and are not representative of the formation fluids.

Because formation fluids were not sampled during Leg 158, one objective of this study was to look for indications recorded in the clay minerals of changes in formation-fluid composition. Clay-mineral compositions were chosen for this study because they incorporate into their structure most of the major and many of the minor and trace elements contained in the original basalt. Clay minerals are very small, usually less than $4 \mu \mathrm{m}$ in diameter, and have net negative surface charge (Brindley and Brown, 1980). Their high surface area and negative charge, providing large reaction surface and ion-exchange capacity, allow clay minerals to track relatively subtle changes in fluid chemical composition. For example, the change from low-pe, low$\mathrm{pH}$ environments of the main upflow zone to higher pe and $\mathrm{pH}$ of entrained seawater in the upper part of the mound may cause decreased mobility of some trace elements, such as Fe and Zn. Such changes may be recorded in the clay minerals. Even though the analytical methods utilized in this study do not distinguish between $\mathrm{FeO}$ and 


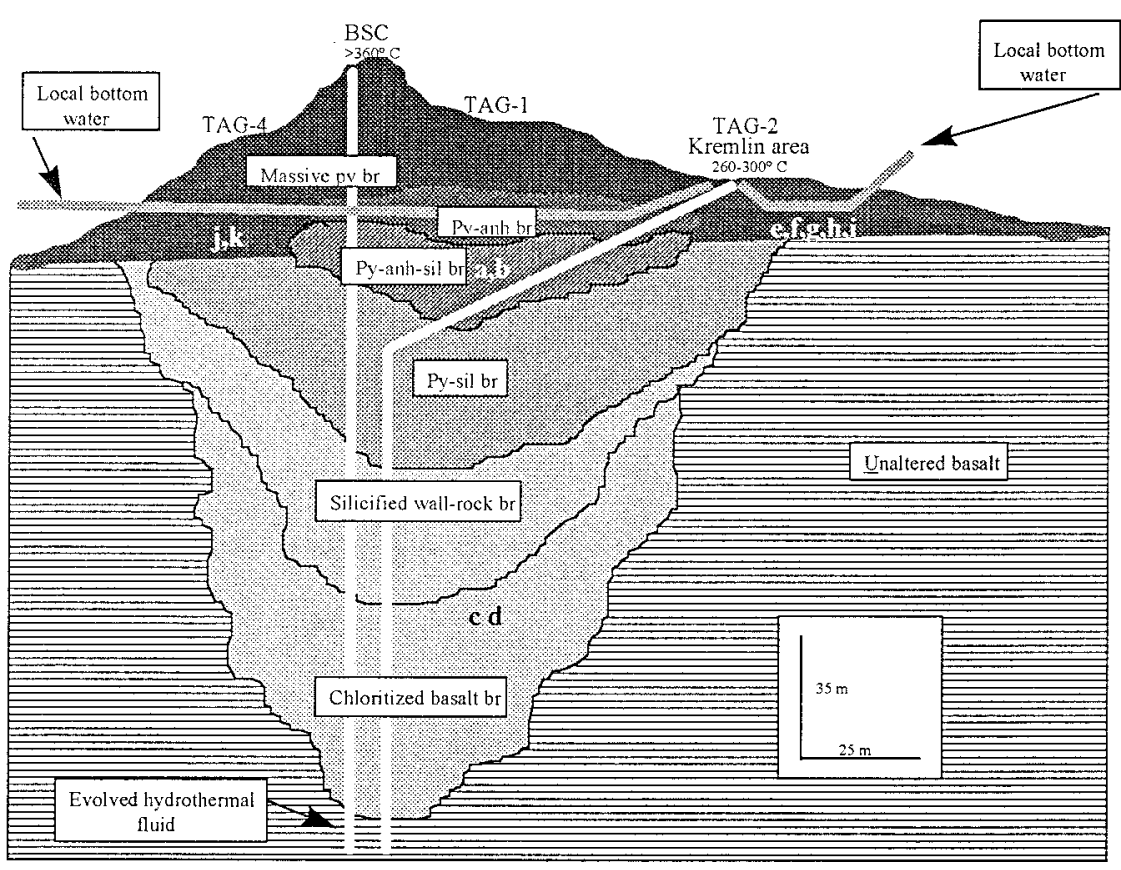

Figure 2. Schematic representation of the TAG mound, showing lithologies and fluid circulation patterns. $\mathrm{BCS}=$ Black Smoker Complex; $\mathrm{py}=$ pyrite; anh $=$ anhydrite; sil $=$ silica; br $=$ breccia . Samples analyzed (designated a through $\mathrm{n}$ on this diagram) are identified in Table 1 (illustration by Thomas Gregory).
$\mathrm{Fe}_{2} \mathrm{O}_{3}$, differences in total $\mathrm{Fe}$, as $\mathrm{Fe}_{2} \mathrm{O}_{3}$, incorporated into clay matrices may indicate changes in chemical environment of formation.

\section{METHODS}

\section{Clay Sample Separation}

Clay minerals were separated from the rock matrix by carefully crushing the portion of the rock of interest, followed by hand separation under a microscope and quantitative settling according to Stoke's Law of the hand-picked mineral separates to separate the $<2$ $\mu \mathrm{m}$-size fraction silicate minerals from the more dense sulfides. The settled mineral separates were oven dried at $30^{\circ} \mathrm{C}$ for $24 \mathrm{hr}$. Mineralogical composition and relative purity of the clay-mineral separates were confirmed by inspection using a scanning electron microscope (SEM) and by X-ray diffraction (XRD) analyses of the oven dried $\left(30^{\circ} \mathrm{C}\right)$, glycolated, and heated $\left(350^{\circ} \mathrm{C}\right.$ and $\left.550^{\circ} \mathrm{C}\right)$ particles. The separation process was repeated until a pure clay-mineral separate was achieved.

\section{Clay Separate Digestion and Analysis}

Clay separates oven dried at $\left(30^{\circ} \mathrm{C}\right)$ for $24 \mathrm{hr}$ were dissolved using fluxed fusion of 0.02-g clay in lithium metaborate/tetraborate, and dissolution of the glass bead in $1 \mathrm{~N} \mathrm{H}_{2} \mathrm{SO}_{4}$ (Brown, 1988). Fluids were stored in polypropylene. Concentrations of major and minor components were determined as follows:

1. Silica, aluminum and titanium by standard colorimetric techniques (Brown, 1988).

2. Calcium, magnesium, potassium, sodium, copper, iron, manganese and zinc by flame atomic absorption spectrophotometry (FAAS) with reference to matched matrix aqueous standard curves for all elements measured and by direct sample standard additions for selected samples as verification of standard matrix match. It should be noted that these analyses do not distinguish between $\mathrm{FeO}$ and $\mathrm{Fe}_{2} \mathrm{O}_{3}$. Thus, iron content is total $\mathrm{Fe}$, as $\mathrm{Fe}_{2} \mathrm{O}_{3}$.

3. Loss on ignition (LOI) by heating to $100^{\circ}-150^{\circ} \mathrm{C}$ then $950^{\circ}-$ $1000^{\circ} \mathrm{C}$ and gravimetric determination of mass loss.

\section{Alteration Rim Bulk Rock Analysis}

Chemical analyses of basalt alteration rims were conducted by inductively coupled plasma-atomic emission spectrophotometry (ICPAES) methods as described in Smith and Humphris (Chap. 17, this volume). These analyses were performed on bulk rock, without any attempt to separate target phases.

Results are shown in Table 1. Sample locations are shown in Figure 2 .

\section{RESULTS \\ Clay Mineralogy}

XRD analyses indicate that five of the mineral separate samples are composed of chlorite (Table 1), as indicated by the presence of a $14-\AA ̊$ reflection that retains its location and magnitude through glycolation and heating. Four of the samples are composed of smectite, as indicated by the presence of a $14-\AA$ reflection that expands to $16-\AA$ upon glycolation and collapses to $10 \AA$ upon heating. Some separated samples (not chemically analyzed and not shown in Table 1) had moderate to minor abundances of other clays (besides chlorite or smectite) that we identified as poorly crystalline smectite or mixed layer clays of d-spacing of $14 \AA$ to $18 \AA$ in the oven-dried $\left(30^{\circ} \mathrm{C}\right)$ particles. Other separated samples (not chemically analyzed and not shown in Table 1) were composed of a mica-like clay, as indicated by the presence of a persistent $10 \AA$ A reflection throughout all treatments. The separated particles containing poorly crystalline smectite, mixed-layer clays, and the mica-like clay all were intimately intermixed with quartz and/or pyrite, and therefore were not suitable for chemical analyses using the techniques described above.

\section{Chemical Composition of Clay Separates}

\section{Major Elements}

Chlorites observed in rocks from the TAG mound are iron rich, with relatively high $\mathrm{MgO}$ and low $\mathrm{SiO}_{2}$ and $\mathrm{Al}_{2} \mathrm{O}_{3}$. Concentrations of $\mathrm{Fe}_{2} \mathrm{O}_{3}$ and $\mathrm{MgO}$ in the chlorites ranged from 23.9 to $40.4 \mathrm{wt} \%$ and 12.8 to $29.0 \mathrm{wt} \%$, respectively (Table 1), which was higher $\mathrm{Fe}_{2} \mathrm{O}_{3}$ and $\mathrm{MgO}$ than the unaltered basalt (Smith and Humphris, Chap. 17, this 
Table 1. Chemical composition of clay minerals and altered bulk rock.

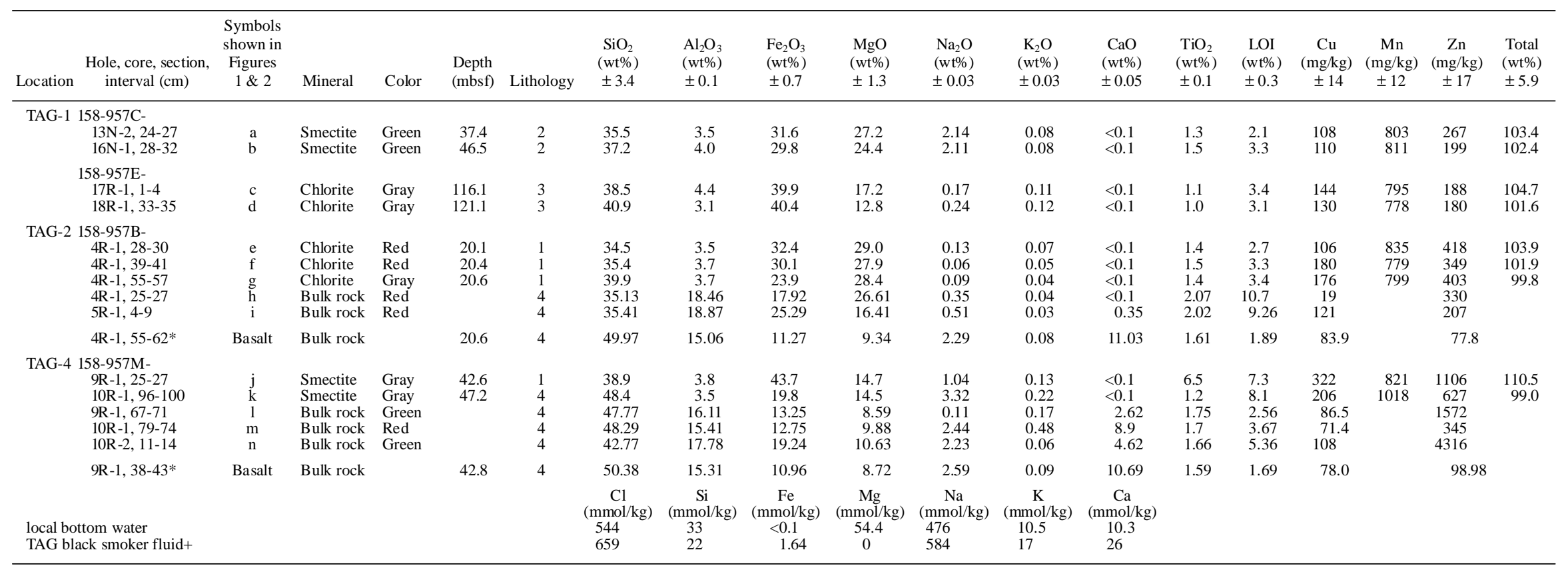

Notes: * = data from Smith and Humphris (Chap. 17, this volume); $+=$ data from Campbell et al. (1988). Lithology: $1=$ massive pyrite breccia, $2=$ pyrite silica breccia, $3=$ chloritized basalt, $4=$ basalt. 
volume). Concentrations of $\mathrm{SiO}_{2}, \mathrm{Al}_{2} \mathrm{O}_{3}, \mathrm{Na}_{2} \mathrm{O}$, and $\mathrm{CaO}$ in the chlorites range from 35.4 to $40.9 \mathrm{wt} \%, 3.5$ to $4.4 \mathrm{wt} \%, 0.24$ to $0.6 \mathrm{wt} \%$, and $<0.1 \mathrm{wt} \%$, respectively, all lower than those in the unaltered basalt (Smith and Humphris, Chap. 17, this volume). $\mathrm{TiO}_{2}$ in the chlorites is near or less than $\mathrm{TiO}_{2}$ in the unaltered basalt.

Chemical composition of the smectites observed in rocks from the TAG mound are similar to those observed in the chlorites, with minor differences. The smectites have a broader range of $\mathrm{Fe}_{2} \mathrm{O}_{3}$ concentrations (19.8-43.7 wt\%) and a similar range of $\mathrm{MgO}$ concentrations (14.5-27.2 wt\%). With one exception, $\mathrm{TiO}_{2}$ in the smectites are near or less than $\mathrm{TiO}_{2}$ in the unaltered basalt. Sample 158-957M-9R-1, 25-27 cm, has anomalously high $\mathrm{TiO}_{2}$ relative to the other clay minerals analyzed. Concentrations of $\mathrm{Na}_{2} \mathrm{O}$ in the smectites are very close to that of the basalt.

\section{Trace Elements in Clay Separates}

Concentrations of $\mathrm{Cu}$ and $\mathrm{Zn}$ in both the chlorites and the smectites are higher than they are in the basalts and are higher in clay samples recovered from shallower depths in the mound than those recovered from deeper in the mound (Table 1). On a mol/mol transfer of $\mathrm{Zn}$ from basalt into secondary silicates, $\mathrm{Zn}$ is enriched by as much as $400 \%$ in the TAG-4 region in the clays relative to the basalt.

\section{Chemical Composition of Basalt Alteration Rims}

\section{Major Elements}

Chemical analyses of bulk-rock basalt alteration rims verify the general trends observed in the clay-mineral separates. Alteration rims are $\mathrm{Fe}$ rich, with relatively high $\mathrm{MgO}$ and low $\mathrm{SiO}_{2}$, compared to the unaltered basalt. For ease of handling, the alteration rims were classified by color: green or red. Concentrations of $\mathrm{Fe}_{2} \mathrm{O}_{3}$ and $\mathrm{MgO}$ in the green rims ranged from 13.3 to $19.2 \mathrm{wt} \%$ and from 8.6 to $10.6 \mathrm{wt} \%$, respectively (Table 1), slightly higher $\mathrm{Fe}_{2} \mathrm{O}_{3}$ and $\mathrm{MgO}$ than in the unaltered basalt. Concentrations of $\mathrm{SiO}_{2}, \mathrm{Al}_{2} \mathrm{O}_{3}, \mathrm{Na}_{2} \mathrm{O}$, and $\mathrm{CaO}$ in the green rims range from 42.7 to $47.8 \mathrm{wt} \%, 16.1$ to $17.8 \mathrm{wt} \%, 2.2$ to 2.4 $\mathrm{wt} \%$, and 2.6 to $4.6 \mathrm{wt} \%$, respectively, all lower than in the unaltered basalt, but closer to values in the basalt than the clay-mineral separates described above. Concentrations of $\mathrm{Fe}_{2} \mathrm{O}_{3}$ and $\mathrm{MgO}$ in the red rims ranged from 12.7 to $25.3 \mathrm{wt} \%$ and 9.9 to $26.6 \mathrm{wt} \%$, respectively (Table 1), higher than in the unaltered basalt and with a wider range of compositions than the green alteration rims. Concentrations of $\mathrm{SiO}_{2}, \mathrm{Al}_{2} \mathrm{O}_{3}, \mathrm{Na}_{2} \mathrm{O}$, and $\mathrm{CaO}$ in the red rims range from 35.1 to 48.3 wt $\%, 15.4$ to $18.8 \mathrm{wt} \%, 0.35$ to $2.4 \mathrm{wt} \%$, and $<0.1$ to $8.9 \mathrm{wt} \%$, respectively, showing a wider range of compositions than the green rims.

\section{Trace Elements in Basalt Alteration Rims}

Concentrations of $\mathrm{Cu}$ in both green and red rims range from 19 to $121 \mathrm{mg} / \mathrm{kg}$, near that of the unaltered basalt $(78-84 \mathrm{mg} / \mathrm{kg} \mathrm{Cu})$. In the red rims, Zn ranges from 207 to $403 \mathrm{mg} / \mathrm{kg}$, slightly higher than is observed in the basalt $(78-99 \mathrm{mg} / \mathrm{kg}$ ), whereas $\mathrm{Zn}$ in the green rims is much greater $(1572-4316 \mathrm{mg} / \mathrm{kg})$ than in both the red rims and the unaltered basalt.

\section{Iron, Silica, and Magnesium}

Of specific interest for the discussion below are relative differences in iron, silica, and magnesium contents in the clay minerals. Smectite recovered from TAG-4, the northwesterly side of the mound, (Sample 158-957M-10R-1, 96-100 cm), contains $\mathrm{SiO}_{2}$, (48.4 wt\%) and $\mathrm{Fe}_{2} \mathrm{O}_{3}(19.8 \mathrm{wt} \%)$ and is closest in silica content to that of the unaltered basalt (50.38 and $10.96 \mathrm{wt} \%$, respectively; Table 1). Smectite separated from the overlying breccia (Sample 158-957M-9R-1, 25$27 \mathrm{~cm}$ ) has lower $\mathrm{SiO}_{2}(38.9 \mathrm{wt} \%)$ and higher $\mathrm{Fe}_{2} \mathrm{O}_{3}(43.7 \mathrm{wt} \%)$. Bulk-rock altered red rim (Sample 158-957M-10R-1, 69-74 cm) and green rims (Samples 158-957M-09R-1, 67-77 cm, and 10R-2, 11-14 cm) contain $\mathrm{SiO}_{2},\left(48.3,47.8\right.$, and $42.7 \mathrm{wt} \%$, respectively) and $\mathrm{Fe}_{2} \mathrm{O}_{3}$ $(12.8,13.3$, and $19.2 \mathrm{wt} \%$, respectively), all very close to that of the basalt.

Chlorites associated with massive pyrite breccia (Samples 158957B-4R-1, 28-30 cm, 4R-01, 39-41 cm, and 4R-1, 55-57 cm) and red alteration rims (Samples 158-957B-4R-01, 25-27 cm, and 5R-1, 4-9 cm) are found at a relatively shallow depth at TAG-2, the southeasterly side of the mound. These chlorites contain $\mathrm{SiO}_{2},(34.5,35.4$, and $39.9 \mathrm{wt} \%$, respectively) and $\mathrm{Fe}_{2} \mathrm{O}_{3}(32.4,30.1$, and $23.9 \mathrm{wt} \%$, respectively), lower silica and higher iron than observed in smectites at TAG-4 and in the basalt. The red rims contain $\mathrm{SiO}_{2}$ (35.13 and 35.41 wt $\%$, respectively) and $\mathrm{Fe}_{2} \mathrm{O}_{3}$ (17.92 and $25.29 \mathrm{wt} \%$, respectively), also lower silica and, in Sample 158-957B-5R-1, 4-9 cm, higher iron than at TAG-4 and in the basalt.

Smectites recovered from pyrite-silica-breccia at a relatively shallow depth at TAG-1 (Samples 158-957C-13N-2, 24-27 cm, and $16 \mathrm{~N}-1,28-32 \mathrm{~cm}$ ) contain $\mathrm{SiO}_{2}(35.5$ and $37.2 \mathrm{wt} \%$, respectively) and $\mathrm{Fe}_{2} \mathrm{O}_{3}$ (31.3 and $29.8 \mathrm{wt} \%$, respectively), similar to the chlorites from TAG-4. Chlorites recovered from the chloritized basalt, from below 115 mbsf at TAG-1, contain $\mathrm{SiO}_{2}$ (38.5 and $40.9 \mathrm{wt} \%$, respectively) and $\mathrm{Fe}_{2} \mathrm{O}_{3}$ (39.9 and $40.4 \mathrm{wt} \%$, respectively), similar to the smectites from TAG-2.

It is also interesting to note that, with the exception of one red rim bulk rock sample (Sample 158-957B-5R-1, 4-9 cm) magnesium contents in the TAG- 4 samples and TAG- 1 samples recovered from below 115 mbsf are lower (8.59-17.2 wt\%) than the magnesium contents in the TAG-2 samples and TAG-1 samples recovered above 50 mbsf (24.4-29.0 wt\%; Table 1).

The smectites and alteration rims from the TAG-4 region have a narrow range of $\mathrm{MgO}$ contents, only slightly higher than the basalt (Table 1). The $\mathrm{MgO}$ contents of chlorites from the TAG-2 region also have a narrow range, but are significantly higher than the basalt. Altered rims from the TAG-2 region have a larger range of $\mathrm{MgO}$ contents (16.4-26.6 wt\%), a range spanning those observed in the clay minerals from both regions. The smectites from the shallower region of TAG-1 are higher (27.2 and $24.4 \mathrm{wt} \% \mathrm{MgO}$ ) than the basalt, more similar to the $\mathrm{MgO}$ contents of the chlorites from TAG-2. The values of chlorites from the deeper region of TAG-1 (17.2 and $12.8 \mathrm{wt} \%$ $\mathrm{MgO})$ are closer to that of the basalt and more similar to the smectites from TAG-4.

\section{DISCUSSION}

Based on preliminary shipboard interpretation of the lithologic sequence observed at TAG (Humphris, Herzig, Miller, et al., 1996; Humphris et al., 1995), entrainment of large quantities of local bottom water into the upper portion of the mound is an important component of fluid circulation through the mound. The shallow component of fluid circulation contributes to the mound-building process by forming large quantities of anhydrite, perhaps as much as $10^{5} \mathrm{~m}^{3}$. Lithologic units below the anhydrite breccias, deeper than about 50 mbsf and beneath the central portion of the mound, have little to no anhydrite. The deeper units are interpreted to be influenced by deeply circulating, more evolved, hydrothermal fluids. One objective of this study was to use clay-mineral chemical compositions to verify the shipboard preliminary interpretation of two sources of fluids circulating through the mound. Another objective of this study was to use authigenic clay-mineral compositions to identify regions of the mound affected by different proportions of mixing between deeply circulating, more evolved fluid, and shallowly entrained, less evolved fluid.

Formation of Fe- and $\mathrm{Mg}$-bearing clay minerals, such as those observed in the TAG rocks, requires an abundant source of $\mathrm{Fe}, \mathrm{Mg}$, and $\mathrm{SiO}_{2}$. Because the local bottom water contains less than detectable concentrations of dissolved $\mathrm{Fe}$ and dissolved $\mathrm{SiO}_{2}$ near $30 \mu \mathrm{M}$ 
(Humphris, Herzig, Miller, et al., 1996), the source of Fe and $\mathrm{SiO}_{2}$ must be the basalt. Similarly, local bottom water contains less than detectable concentrations of dissolved $\mathrm{Zn}$ and $\mathrm{Cu}$. Therefore, enrichments of $\mathrm{Cu}$ and $\mathrm{Zn}$ observed by shipboard investigations in upper lithologic units must also be derived from the basalt. In contrast, sources of $\mathrm{Mg}$ can be either or both the basalt and seawater. The Kremlin area of the TAG mound is a region of white smokers with venting temperatures between $260^{\circ}$ and $300^{\circ} \mathrm{C}$ (Humphris et al., 1995). Mg is quantitatively removed from seawater early in its hydrothermal evolution history when heated to this range of temperatures (e.g. Bischoff and Dickson, 1975; Bischoff and Seyfried, 1978; Von Damm, 1988). Thus, major-element composition of the fluids circulating to different depths with different evolution histories are expected to be different. Clay minerals formed in association with fluids of different circulation histories may reflect this difference. We will use $\mathrm{Fe}_{2} \mathrm{O}_{3} / \mathrm{SiO}_{2}$ values and $\mathrm{MgO}$ and $\mathrm{Zn}$ concentrations in clay minerals from the TAG mound to infer variable degrees of mixing between two such different fluids in different regions and at different times during the accumulation history of the mound.

\section{Iron and Silica}

Data shown in Figure 3 suggest two distinct trends of $\mathrm{Fe}_{2} \mathrm{O}_{3} / \mathrm{SiO}_{2}$ in the clay minerals. $\mathrm{Fe}_{2} \mathrm{O}_{3} / \mathrm{SiO}_{2}$ of the unaltered basalt is at the intersection of the two trend lines. Smectites associated with the pyritesilica-breccia were found at relatively shallow depths in the TAG-1 region (Samples 158-957C-13N-2, 22-27 cm, and 16N-1, 28-32 cm; designated $a$ and $b$ in Fig. 2). Chlorites were found below $115 \mathrm{mbsf}$ at the TAG-1 region, associated with chloritized basalt (Samples 158-957E-17R-1, 1-4 cm, and 18R-1,33-35 cm; designated $\mathrm{c}$ and $\mathrm{d}$ in Fig. 2). The line connecting clay minerals from the shallow regions of TAG-1 and from TAG-4 to the unaltered basalt has a steeper slope than the line connecting clay minerals from TAG-2 and the deeper regions of TAG-1 to unaltered basalt. Samples designated j and k (Fig. 2; Samples 158-957M-9R-1, 25-27 cm, and 10R-1, 96-100 cm, respectively), the smectites from TAG-4, cluster along the same trend as the chlorites from TAG-1, with k nearer in composition to the unaltered basalt and $\mathrm{j}$ nearer the TAG- 1 chlorites. Samples designated e, f, and g (Fig. 2; Samples 158-957B-4R1, 20-30 cm, 4R-1, 39-41 $\mathrm{cm}$, and $4 \mathrm{R}-1,55-57 \mathrm{~cm}$, respectively) cluster along the same trend as the smectites from TAG-1.

The $\mathrm{Fe}_{2} \mathrm{O}_{3} / \mathrm{SiO}_{2}$ relationship observed in the red and green alteration rims is less clear. On first inspection, the $\mathrm{Fe}_{2} \mathrm{O}_{3} / \mathrm{SiO}_{2}$ data shown in Figure 3 for all the alteration rims plot along the more shallowly sloping line. However, it should be remembered that the alteration rim analyses were performed on bulk-rock samples. The presence of quartz intimately intermixed with the clay minerals would dilute the iron concentration measured and enrich the silica concentration measured relative to the clay-mineral composition, thus moving the point plotted for that sample down and to the right on the diagram.

The distinctly different trends between $\mathrm{Fe}_{2} \mathrm{O}_{3} / \mathrm{SiO}_{2}$ and the basalt composition suggest that different regions of the mound have been influenced by fluids of different $\mathrm{Fe}_{2} \mathrm{O}_{3} / \mathrm{SiO}_{2}$ relative ratio. The presence of abundant authigenic quartz and pyrite, as are observed in the TAG rocks, is consistent with a fluid that is chemically evolving through precipitation of secondary solids.

\section{Magnesium}

Figure 4, showing relative proportions of $\mathrm{Fe}_{2} \mathrm{O}_{3}$ and $\mathrm{MgO}$ in claymineral seperates and altered rims, suggests two fields of $\mathrm{Fe}_{2} \mathrm{O}_{3} / \mathrm{MgO}$ relative ratio. (Sample designations a through $\mathrm{n}$ are given in Table 1 and refer to the same samples discussed above.) Samples a, b, e, f, g, and $\mathrm{h}$ plot in a field of relatively high $\mathrm{MgO}$. The clay minerals that plot in this field were recovered from TAG-2 and from the shallow portion of TAG-1. Samples c, d, j, k, l, m, and n plot in the field of relatively lower $\mathrm{MgO}$ and were recovered from the deeper portion of TAG- 1 and from TAG-4. One sample from TAG-2, sample i, plots in this field of relatively lower $\mathrm{MgO}$. However, it should be noted that $\mathrm{MgO}$ and $\mathrm{Fe}_{2} \mathrm{O}_{3}$ concentrations of sample i (Sample 158-957B-5R1, 4-9 $\mathrm{cm}$ ) were measured on bulk rock from a red alteration rim. As discussed above, the presence of quartz would dilute the measured values of major oxides other than silica.

The fields of differing $\mathrm{Fe}_{2} \mathrm{O}_{3} / \mathrm{MgO}$ suggest that chemical reactions associated with fluids circulating at shallow depths through the southeasterly side of the mound at TAG-2 and the upper portion of the central region of the mound at TAG-1 are producing clay minerals, both smectite and chlorite, with relatively high $\mathrm{MgO}$ contents, whereas chemical reactions associated with fluids circulating through the westerly (TAG-4) and deep central (TAG-1) portion of the mound are producing clay minerals, both smectite and chlorite, with relatively low $\mathrm{MgO}$ contents. Thus, TAG-4 and the deeper portion of the central part of the mound were exposed to relatively low-Mg fluids at the time the clay minerals were formed. In contrast, the TAG-2 area and the shallower portions of the central part of the mound were exposed
Figure 3. Weight percent $\mathrm{SiO}_{2}$ and $\mathrm{Fe}_{2} \mathrm{O}_{3}$ in clay minerals and alteration rims. Sample identifications (a through $\mathrm{n}$ ) are given in Table 1 and are located in Figure 2. The lines indicate trends of change in $\mathrm{SiO}_{2}$ and $\mathrm{Fe}_{2} \mathrm{O}_{3}$ from the starting material, unaltered basalt, to the measured concentrations in the TAG clay minerals in various regions of the TAG active hydrothermal mound. The more shallowly sloping line shows the trend observed for TAG-2 and the shallower region of TAG-1. The more steeply sloping line shows the trend for TAG-4 and the deeper region of TAG- 1 .

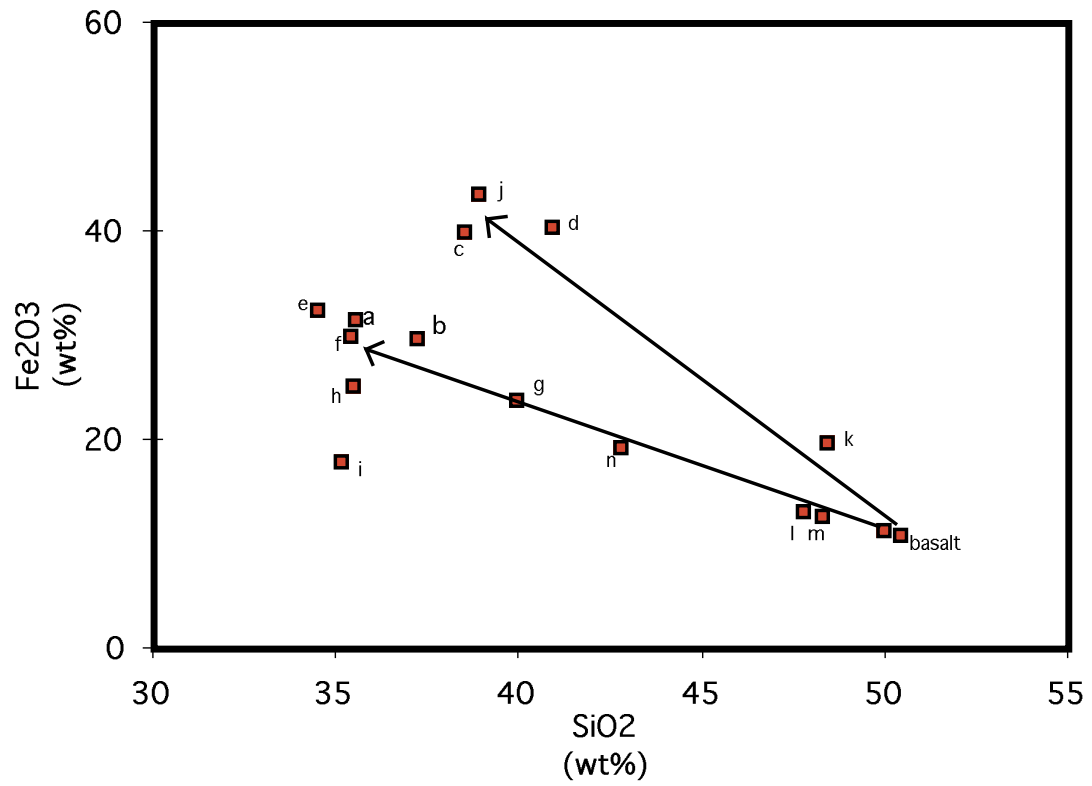




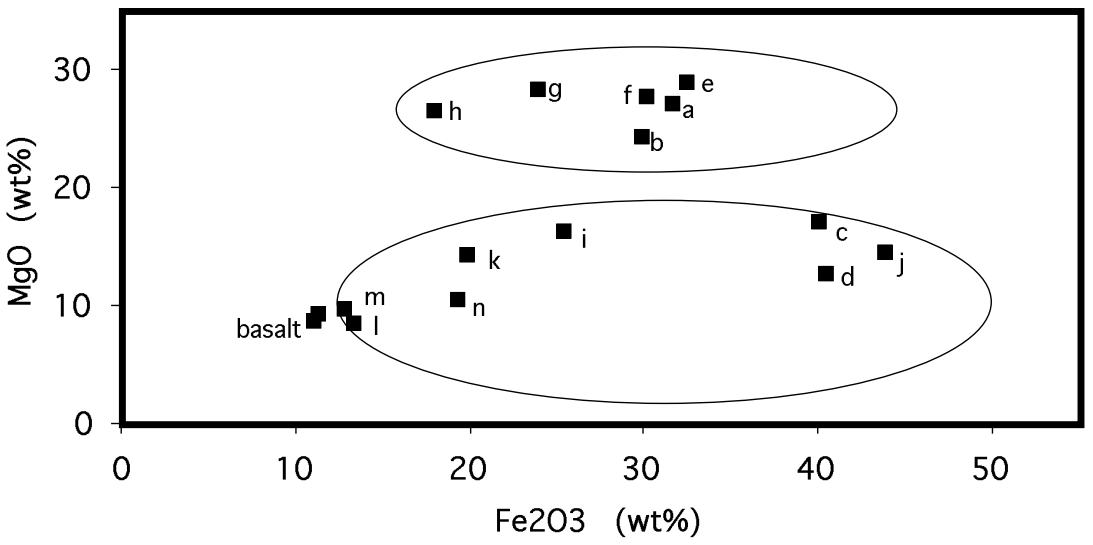

Figure 4. Weight percent $\mathrm{Fe}_{2} \mathrm{O}_{3}$ and $\mathrm{MgO}$ in clay minerals and alteration rims. The group of samples with relatively high $\mathrm{MgO}$ content ( $\mathrm{a}, \mathrm{b}, \mathrm{e}, \mathrm{f}, \mathrm{g}$, and $\mathrm{h}$ in the upper ellipse) are from the shallower region of TAG- 1 and from TAG-2. The group of samples with relatively low $\mathrm{MgO}$ content (c, $\mathrm{d}, \mathrm{i}, \mathrm{j}, \mathrm{k}, \mathrm{l}, \mathrm{m}$, and $\mathrm{n}$ in the lower ellipse) are from the deeper region of TAG- 1 and from TAG- 4 . to more Mg-enriched fluids during the episode(s) of clay-mineral formation.

\section{Zinc}

Another important finding is that $\mathrm{Zn}$ concentrations in smectite and chlorite are higher around the margins of the mound (TAG-2 and TAG-4) than in the central portion of the mound and that the red alteration rims have lower $\mathrm{Zn}$ content than the green rims (Table 1). The highest $\mathrm{Zn}$ concentrations were measured in the TAG- 4 area. Zinc in the chlorites and smectites from the TAG-1 region are relatively low, with the highest $\mathrm{Zn}$ concentrations in this region found in the shallowest samples. Therefore, those regions with clay minerals that are relatively enriched in $\mathrm{Zn}$ are the peripheral regions of the mound, generally associated with the massive pyrite breccia and interpreted to be chimney talus (Humphris et al., 1995). The variability in $\mathrm{Zn}$ concentrations associated with clay minerals may represent differences in dissolved $\mathrm{Zn}$ in circulating fluids. The variation in $\mathrm{Zn}$ associated with different colors of the alteration rims also implies specific fluid zones. This is consistent with the shipboard interpretation that $\mathrm{Zn}$ has been remobilized during late-stage circulation of fluids and reprecipitated as sphalerite-rich chimneys and domes (Humphris, Herzig, Miller, et al., 1996).

\section{Mixing of Fluids from Different Sources}

The observed distributions of $\mathrm{Fe}_{2} \mathrm{O}_{3} / \mathrm{SiO}_{2}, \mathrm{MgO}$, and $\mathrm{Zn}$ in chlorites and smectites from the TAG mound are consistent with two fluid sources, one more evolved fluid from a high-temperature reaction zone at depth, and the other local bottom water entrained into shallow portions of the mound and less evolved than the deeply circulating fluid. These data suggest that mixing of the two fluids within the mound is not uniformly distributed. Locally derived, less evolved water has a larger influence on the clay minerals formed in the southeastern TAG-2 and shallow central TAG-1 regions than in other parts of the mound. This is consistent with measured exit temperatures of present-day fluids $\left(260^{\circ}-300^{\circ} \mathrm{C}\right)$ at the TAG-2 region (Campbell et al., 1988; Humphris et al., 1995, and references therein).

In contrast, the clay minerals recovered from the deeper central portion of the mound were formed in association with a greater proportion of more evolved hydrothermal fluids. This is consistent with the fluids presently exiting with temperature in excess of $360^{\circ} \mathrm{C}$ from the apex of the mound at the Black Smoker Complex (Campbell, et al., 1988; Humphris et al., 1995, and references therein). Based on the clay-mineral composition in the shallow portions of TAG-1, fluids presently exiting at the Black Smoker Complex must pass rapidly through the talus mound with little loss of dissolved components into clay minerals. The clay minerals from the shallow regions of TAG-1 analyzed during this project were apparently derived from an episode of clay formation from fluids more similar to those presently exiting from the TAG-2 region (that is, fluids derived from mixing a greater proportion of less evolved fluids with a lesser proportion of more evolved fluids).

Interpretation of the TAG-4 region data is more ambiguous. Becker et al. (1993) suggest that the northwesterly side of the TAG mound is a region of relatively low heat flow, perhaps a zone of bottom-water entrainment into the mound. However, the clay-mineral data reflect authigenic mineral formation from a more evolved fluid, perhaps similar to that presently exiting from the Black Smoker Complex and influencing the deeper portions of the central mound. Also, $\mathrm{Zn}$ contents in the clay minerals and green alteration rims from the TAG-4 region are more consistent with a fluid relatively high in dissolved Zn. Such discordance between trace- and major-element chemical composition may be explained in terms of the role a trace element, such as Zn, may play in the clay-mineral structure. Zinc may not reside in a major structural site in the clay mineral (Brindley and Brown, 1980). Whereas the major-element composition $\left(\mathrm{SiO}_{2}\right.$, $\mathrm{Fe}_{2} \mathrm{O}_{3}, \mathrm{MgO}$ ) of the clay mineral reflects the composition of the fluid as the mineral is forming, the $\mathrm{Zn}$ may be acquired from a different composition fluid, through ion exchange at any time after the mineral has formed. The contrast of major- and trace-element clay-mineral chemical composition at TAG-4, as well as the association between $\mathrm{Zn}$ and alteration color, implies multiple episodes of fluid circulation.

Based on the chemical composition of clay minerals at the TAG mound, it is clear that construction of the mound and formation of authigenic minerals results from mixing of fluids from two different sources. Mixing between the two fluids in the subsurface is variable in time and space. The present-day venting fluid compositions do not account for the observed clay-mineral composition. Comparison of clay-mineral compositions from the central portion of the mound and the southeasterly portion of the mound suggests that the shallow central and southeasterly portions of the mound have been exposed to fluids derived from a mixture of locally entrained bottom water and deeply circulated, highly evolved hydrothermal fluid. The deep central portions of the mound have been exposed to a greater proportion of more evolved hydrothermal fluids. Fluids circulating through the northwesterly portion of the mound may have been hotter in the past than they are now.

\section{CONCLUSIONS}

1. Clay minerals separated from rocks recovered during Leg 158 at the TAG hydrothermal mound consist of chlorite and smectite. A mica-like clay and mixed-layer clays are also present, but in considerably lesser amounts.

2. The concentrations of $\mathrm{SiO}_{2}, \mathrm{Fe}_{2} \mathrm{O}_{3}, \mathrm{MgO}$, and $\mathrm{Zn}$ are different in various regions of the mound, reflecting differences in the composition of the fluid from which they formed. 
3. Clay minerals in the shallow portions of the central mound and the southeasterly portion of the TAG mound reflect a greater proportion of mixing between a locally derived, less evolved fluid and a deeply circulating, more evolved hydrothermal fluid.

4. Clay minerals in the deeper portion of the central mound and the northwesterly portion of the mound reflect fluids with a greater proportion of highly evolved hydrothermal fluid.

\section{ACKNOWLEDGMENTS}

We gratefully acknowledge financial support provided by USSSP for this work. Thanks, also, to Dr. Joris Gieskes of Scripps Institution of Oceanography, an anonymous reviewer, and the ODP Editorial Review Board for valuable constructive criticism that improved this manuscript.

\section{REFERENCES}

Becker, K., Von Herzen, R.P., and Rona, P.A., 1993. Conductive heat flow measurements using Alvin at the TAG active hydrothermal mound, MAR at $26^{\circ}$ N. Eos, 74 (Suppl.): 99.

Bischoff, J.L., and Dickson, F.W., 1975. Seawater-basalt interaction at $200^{\circ} \mathrm{C}$ and 500 bars: implications for origin of seafloor heavy metal deposits and regulation of seawater chemistry. Earth Planet. Sci. Lett., 25:385-397.

Bischoff, J.L., and Seyfried, W.E., 1978. Hydrothermal chemistry of seawater from $25^{\circ} \mathrm{C}$ to $350^{\circ} \mathrm{C}$. Am. J. Sci., $278: 838-860$.

Brindley, G.W., and Brown, G. (Eds.), 1980. Crystal Structures of Clay Minerals and Their X-ray Identification. Mineral. Soc. London Monogr., 5.

Brown, T., 1988. Wet chemical analysis of marine sediments: Applications to hydrothermal sediments of the Guaymas Basin [Master's thesis]. San Diego State Univ.

Campbell, A., Klinkhammer, J., Palmer, M., Bowers, T., Edmond, F., Lawrence, J.R., Casey, C., Thompson, G., Humphris, S., Rona, P., and
Karson, J., 1988. Chemistry of hot springs on the Mid-Atlantic Ridge. Nature, 335:514-519.

Fujioka, K., Von Herzen, R.P., and the Shipboard Scientific Party, 1994. Shinkai-Yokosuka MODE '94 Leg 2 Cruise Summary: studies of an active hydrothermal mound at the TAG area on the Mid-Atlantic Ridge. Interridge News, 3:21-22.

Humphris, S.E., Herzig, P.M., Miller, D.J., Alt, J.C., Becker, K., Brown, D., Brügmann, G., Chiba, H., Fouquet, Y., Gemmell, J.B., Guerin, G., Hannington, M.D., Holm, N.G., Honnorez, J.J., Itturino, G.J., Knott, R., Ludwig, R., Nakamura, K., Petersen, S., Reysenbach, A.-L., Rona, P.A., Smith, S., Sturz, A.A., Tivey, M.K., and Zhao, X., 1995. The internal structure of an active sea-floor massive sulphide deposit. Nature, 377:713-716.

Humphris, S.E., Herzig, P.M., Miller, D.J., et al., 1996. Proc. ODP, Init. Repts., 158: College Station, TX (Ocean Drilling Program).

Rona, P.A., Hannington, M.D., Raman, C.V., Thompson, G., Tivey, M.K., Humphris, S.E., Lalou, C., and Petersen, S., 1993. Active and relict seafloor hydrothermal mineralization at the TAG hydrothermal field, MidAtlantic Ridge. Econ. Geol., 88:1987-2013.

Tivey, M., Humphris, S.E., Thompson, G., Hannington, M.D., and Rona, P.A., 1994. Deducing patterns of fluid flow and mixing within the TAG active hydrothermal mound using mineralogical and geochemical data. $J$. Geophys. Res., 100:12527-12555.

Von Damm, K.L., 1988. Systematics of and postulated controls on submarine hydrothermal solution chemistry. J. Geophys. Res., 93:4551-4561. , 1995. Controls on the chemistry and temporal variability of seafloor hydrothermal fluids. In Humphris, S.E., Zierenberg, R.A., Mullineaux, L.S., and Thomson, R.E. (Eds.), Seafloor Hydrothermal Systems: Physical, Chemical, Biological, and Geological Interactions. Am. Geophys. Union, 91:222-247.

Date of initial receipt: 31 May 1996

Date of acceptance: 10 January 1997

Ms 158SR-221 